\title{
Diffusion cell investigations into the acidic degradation of organic coatings
}

\author{
Møller, Victor Buhl; Wang, Ting; Dam-Johansen, Kim; Frankær, Sarah Maria ; Kiil, Søren
}

Published in:

Journal of Coatings Technology and Research

Link to article, DOI:

$10.1007 / \mathrm{s} 11998-018-0094-z$

Publication date:

2018

Document Version

Peer reviewed version

Link back to DTU Orbit

Citation $(A P A)$ :

Møller, V. B., Wang, T., Dam-Johansen, K., Frankær, S. M., \& Kiil, S. (2018). Diffusion cell investigations into the acidic degradation of organic coatings. Journal of Coatings Technology and Research, 1201-1215. https://doi.org/10.1007/s11998-018-0094-z

\section{General rights}

Copyright and moral rights for the publications made accessible in the public portal are retained by the authors and/or other copyright owners and it is a condition of accessing publications that users recognise and abide by the legal requirements associated with these rights.

- Users may download and print one copy of any publication from the public portal for the purpose of private study or research.

- You may not further distribute the material or use it for any profit-making activity or commercial gain

- You may freely distribute the URL identifying the publication in the public portal 


\title{
Diffusion cell investigations into the acidic degradation of organic coatings
}

\author{
Victor Buhl Møller ${ }^{a *}$, Ting Wang ${ }^{a \dagger}$, Kim Dam-Johansen $^{a \ddagger} ;$ Sarah Maria Frankær ${ }^{b}$, Søren Kiil ${ }^{a}$ \\ ${ }^{a}$ CoaST, Department of Chemical and Biochemical Engineering,
}

Technical University of Denmark, DTU, Building 229, DK-2800 Kgs. Lyngby, Denmark

${ }^{b}$ Hempel A/S, Lundtoftegårdsvej 91, DK-2800 Kgs. Lyngby, Denmark

\begin{abstract}
Protective organic coatings work by preventing contact between an aggressive environment and a vulnerable substrate. However, the long required lifetime of a barrier coating provides a challenge when attempting to evaluate coating performance. Diffusion cells can be used as a tool to estimate coating barrier properties and lifetime. In this work, a diffusion cell array was designed, constructed, and compared to previous designs, with simplicity being the most important design parameter. Sulfuric acid diffusion through five different coatings was monitored using a battery of cells and a mathematical model was developed to simulate the experimental data and to study diffusion mechanisms.
\end{abstract}

The diffusion cells allowed an objective and fast analysis of coating barrier properties. It was found that sulfuric acid deteriorated these properties as it diffused through the films. This was also expressed in the modeling results, where a three-step time-dependence of the diffusion coefficient was required to simulate both acid breakthrough-time and the subsequent steady state flux. A vinyl ester based coating proved to be the most effective barrier to sulfuric acid diffusion, followed by a polyurethane coating. Amine-cured novolac epoxies provided the least effective protection.

\footnotetext{
${ }^{*}$ Tel.: +45-4525-2923 E-mail address: vibum@kt.dtu.dk

$\dagger$ E-mail address: tinwan@kt.dtu.dk

${ }^{\ddagger}$ Tel.: +45-4525-2845 E-mail address: kdj@kt.dtu.dk

${ }^{\S}$ Tel.: +45-4527-3633 E-mail address: samfr@hempel.com

๑ Corresponding author. Tel.: +45-4525-2827 E-mail address: sk@kt.dtu.dk
} 
Keywords: Permeation rate, Failure mechanism, Diffusion coefficient, Barrier properties, Mathematical modeling. 


\section{Nomenclature}

$\begin{array}{ll}A & \text { Effective diffusion area }\left[\mathrm{m}^{2}\right] \\ \alpha & \text { Plasticization power }[\mathrm{l} / \mathrm{mol}] \\ C & \text { Concentration }[\mathrm{mol} / \mathrm{l}] \\ D & \text { Diffusion coefficient }\left[\mathrm{m}^{2} / \mathrm{s}\right] \\ D_{0} & \text { Zero concentration diffusion coefficient }\left[\mathrm{m}^{2} / \mathrm{s}\right] \\ F & \text { Ion flux }\left[\mathrm{mol} / \mathrm{m}^{2} \cdot \mathrm{s}\right] \\ l_{0} & \text { Coating thickness }[\mathrm{m}] \\ t & \text { Time }[\mathrm{s}] \\ V & \text { Volume }\left[\mathrm{m}^{3}\right] \\ l & \text { Position in the coating film }[\mathrm{m}]\end{array}$

Subscripts

B Breakthrough

D Donor chamber

degraded Acid-exposed

dry Dry

i Initial

lag Time lag

sat Saturated

R Receiver chamber

SS Steady state

T Transient state

virgin Non-acid-exposed 


\section{Introduction}

If $\mathrm{H}^{+}$ions permeate through a coating film in low $\mathrm{pH}$ environments, the underlying steel or concrete substrate will be compromised. This may lead to damaged constructions or process equipment. The low pH environments are found many places in the chemical industry [1]. One example is processing of copper ore, where agitated leaching tanks are used. Such a continuously stirred reactor contains a particularly aggressive environment, consisting of warm sulfuric acid and fine particles [2, 3].

Effective barrier coatings are expected to have lifetimes of 15 years or more [4]. Therefore, testing with conventional immersion, where the time to failure is recorded, is a challenge. A simple principle for monitoring ionic diffusion is the diffusion cell, consisting of two chambers separated by a free coating film, as shown in Fig. 1. The set-up works with a concept similar to an H-cell, which has been used for fluid diffusion measurements [5]. In the diffusion cell, the chemicals will diffuse from the Donor chamber, through a coating film and into the Receiver chamber, where the concentration change is monitored using an ion selective probe.

In the past, a range of liquid diffusion cells have been used to monitor ion permeation through organic coatings. Studies include investigations into the effects of formulation parameters on ionic diffusion rates [6, 7], estimation of the ionic flux through coatings [8] or along interfaces [9], and diffusion mechanisms [10]. Diffusion cells have also been used to estimate diffusion coefficients of ions through protective coatings [7-9]. For an overview of permeation studies in barrier coatings see the review paper by Pajarito and Kubouchi [11].

A diffusion cell can be used to map the barrier properties of protective coatings, and, due to its simplicity, the concept is also useful in an industrial perspective. However, a thorough under- 


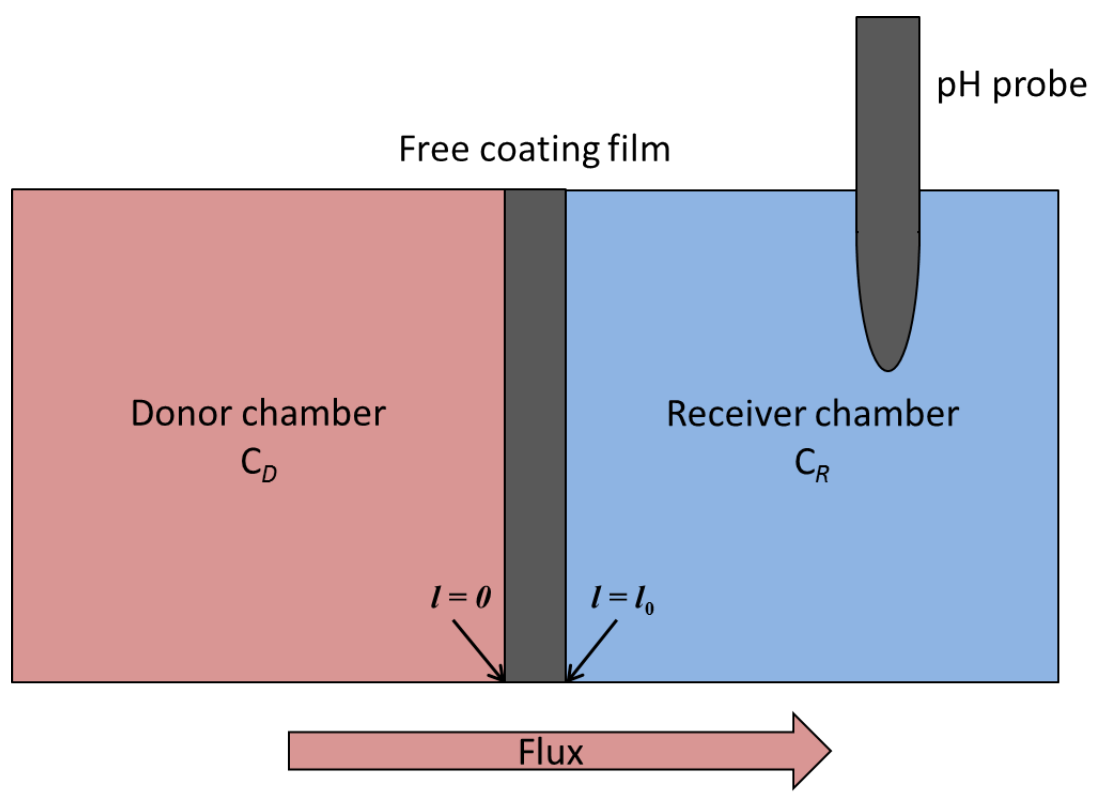

Figure 1: Basic diffusion cell concept. A free coating film of thickness $l_{0}$ separates the two chambers. Solute molecules diffuse from the Donor to the Receiver chamber.

standing of diffusion mechanisms in these cells is lacking, and the effects of chemical reactions within a coating film are poorly understood. In the current work, a diffusion cell with the simplest design possible was constructed. Breakthrough times and steady state flux data were measured, and, using a mathematical model, acid diffusion coefficients were estimated for selected coatings. The model was also used as a tool to investigate diffusion mechanisms and predict coating lifetimes.

\section{Previous diffusion cell designs}

Past work using liquid diffusion cells include a variety of different designs. However, they all share the concept presented in Fig. 1, with the exceptions of Allen [12], who relied on volume changes, and Romhild et al. [13] who only used an acid filled Donor chamber, and monitored the cell weight loss as chemicals permeated the coating and evaporated. The most common designs are described in Table 1. References to gas diffusion cells were not relevant for this work and 
were omitted.

Most diffusion cell designs use ion-selective probes that can measure the ionic flux in the Receiver chamber. The $\mathrm{Na}^{+}, \mathrm{Cl}^{-}$, and $\mathrm{H}^{+}$ions have been tracked in past work, but probes are available that can be used to detect many other types of ions. Some cell designs use stirring in the Donor and/or Receiver chambers to ensure a homogeneous concentration, but this feature has the disadvantage that the cell design becomes more complex [6-9]. Liquid volumes in the chambers can change throughout an experiment and therefore aerating holes are present in some cells to ensure a constant atmospheric pressure. However, this also increases the evaporation rate of volatile chemicals [7-9]. The volume of the Donor chamber, for some designs [8, 9], is larger than that of the Receiving chamber. This is done to promote a constant concentration in the Donor chamber, but it also increases the size of the cell. Heating is typically not used, but it can be required to simulate certain industrial conditions or to accelerate diffusion rates [10]. 
Table 1: Overview of selected liquid diffusion cell designs. The Donor to Receiving chamber volume ratio is provided as $V_{D} / V_{R}$.

\begin{tabular}{|c|c|c|c|c|c|c|c|c|}
\hline Cell type & Measurement & Coating type & Substrate & Stirring & $V_{D} / V_{R}$ & Pressure conditions & Heating & Reference (year) \\
\hline Ionic & Ion flux $\left(\mathrm{H}^{+}\right)$ & Polyamide & None & None & 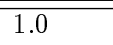 & Closed chambers & Both chambers & 10 (2006) \\
\hline Osmotic & Volume change & Vinyl ester & None & None & 1.0 & NA & None & 12] (1979) \\
\hline Ionic & Ion flux $\left(\mathrm{Cl}^{+}\right)$ & Waterborne & Kraft paper & Receiver chamber & 2.7 & Open Donor chamber & None & 8 \\
\hline Ionic & Ion flux $\left(\mathrm{H}^{+}\right)$ & Polyvinyl alcohol and polyethylene glycol & None & Both chambers & 1.0 & Open Donor chamber & None & 7] $(2005)$ \\
\hline Ionic & Ion flux $\left(\mathrm{Na}^{+}\right)$ & Epoxy & Kraft paper & Receiver chamber & 2.8 & Open Donor chamber & None & 9] (2010) \\
\hline Ionic & Ion flux $\left(\mathrm{H}^{+}\right)$ & Polyvinyl alcohol and epoxy & None & Both chambers & 1.0 & Closed chambers & None & 6] $(2004)$ \\
\hline Single chamber & Weight change & Vinyl ester and liquid crystal polymers & None & None & - & Closed chamber & Yes & 13 \\
\hline
\end{tabular}




\section{New diffusion cell design}

Important design criteria for the acid diffusion cell of this work were: simple to produce and upscale to an array of cells, compact design, and the cell material should be chemically inert and transparent. The cell was constructed using Plexiglas, poly(methyl methacrylate). This material is inert to the acid concentrations of importance (down to $\mathrm{pH} \approx 0$ ), and is transparent, allowing observation of changes in the coating sample or liquid levels in the cell during experimentation. According to the material supplier (RIAS), the PMMA material should not be used above $90{ }^{\circ} \mathrm{C}$, nor should it be used in contact with concentrated sulfuric acid. The current investigation took place at $75{ }^{\circ} \mathrm{C}$ in diluted sulfuric acid, therefore PMMA is not expected to have an influence on the measured $\mathrm{pH}$ change.

The major design differences between the current and previous diffusion cell designs are the lack of aerating holes and stirring, and the possibility of heating. No aerating holes were used; cell chambers were equilibrated with the atmospheric pressure during a $\mathrm{pH}$ measurement, where rubber stoppers blocking the feed holes were removed. Moggridge et al. [14] observed that stirring was insignificant in either chamber of an ionic diffusion cell and therefore stirring was not used in the current cell. The Donor chamber volume was made 2.8 times larger than the Receiving chamber, causing a near constant Donor chamber concentration during experimentation. Rather than integrating heating in the cell design, it was established by inserting the entire cell into an oven.

\section{Diffusion cell details}

The new cell is shown in Fig. 2 with a schematic view in Fig. 3. Cell dimensions are 150x80x80 $\mathrm{mm}$. The liquid volume in the Donor and Receiver chamber are $92.1 \mathrm{~cm}^{3}$ and $33.1 \mathrm{~cm}^{3}$, respect- 
ively. The coating film used for experimentation is placed between the two chambers, and the connections are sealed with O-rings inserted into each chamber wall as shown in Fig. 3. The chambers can be assembled using screws and bolts through holes in the flanges, creating a tight seal between O-ring and coating film. The effective coating surface area for diffusion is $9.1 \mathrm{~cm}^{2}$. A single feeding hole is placed in the Donor chamber for filling and emptying liquid, while two feeding holes are present in the Receiver chamber. The two access holes for the Receiver chamber were made to avoid overflow when inserting the $\mathrm{pH}$ probe. A total of eight diffusion cells were constructed and used for experimentation.

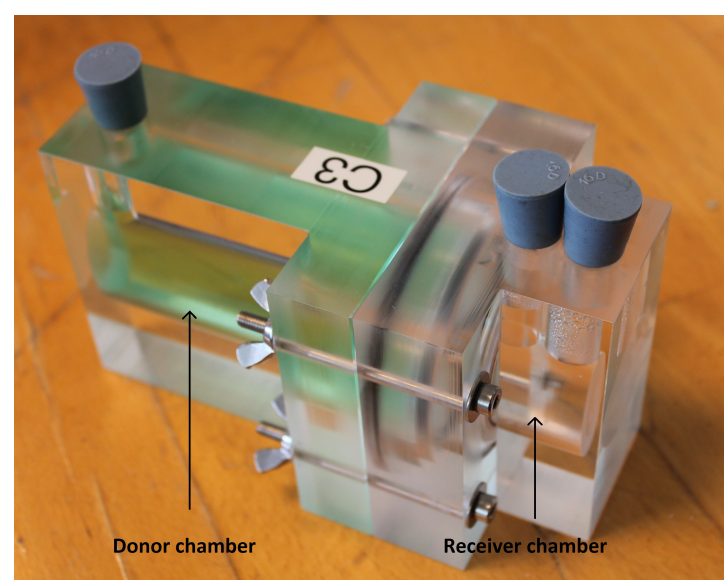

Figure 2: Ionic diffusion cell with rubber stoppers in the access holes.

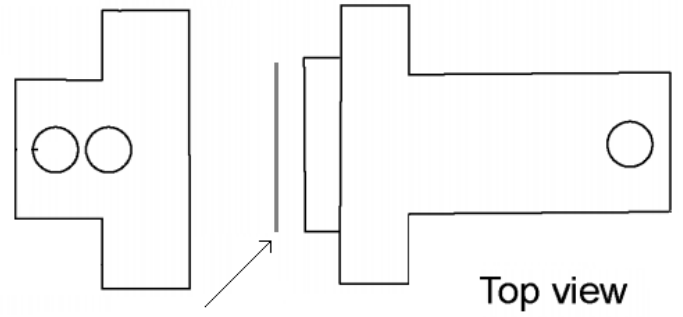

Free coating film placement

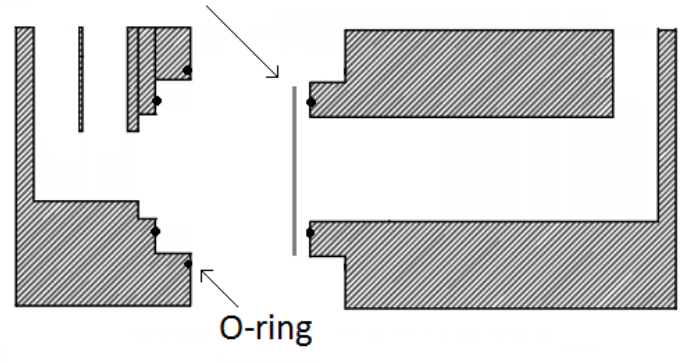

Front cross-section view

Figure 3: Schematic cross section view of the diffusion cell.

\section{Experimental conditions}

Two types of experiments were performed in the current work. The first type, referred to as "Preliminary" conditions, were used as an investigation into the effects of water saturation. These experiments were performed at ambient temperatures with a single coating type. The second type of experiment is referred to as "Harsh" conditions, and is a replication of the chemical 
environment and temperature in an agitated leaching tank [3]. Four different coating types were used for experimentation. Table 2 provides an overview of the experimental conditions and chemicals applied.

Table 2: Chemical environments in the Donor chamber. Harsh conditions simulate the chemical environment in an industrial leaching reactor. The Receiver chamber contained demineralized water in all experiments.

\begin{tabular}{lll} 
Condition & Preliminary & Harsh \\
\hline $\mathrm{H}_{2} \mathrm{SO}_{4}[\mathrm{~mol} / \mathrm{l}]$ & 1.08 & 0.13 \\
$\mathrm{pH}$ & -0.03 & 0.9 \\
$\mathrm{Cu}(\mathrm{II})[\mathrm{g} / \mathrm{l}]$ & 0 & 4.1 \\
Temperature $\left[{ }^{\circ} \mathrm{C}\right]$ & $20.0 \pm 1.0$ & $68.5 \pm 2.5$ \\
\hline
\end{tabular}

\section{Experimental procedure}

For all experiments, the procedure was the same. Before inserting and fastening the free coating film in the diffusion cell, the dry film thickness was measured using an Elcometer 355. The experimental liquids and assembled cell were heated separately to the required temperature, whereafter the Receiver and Donor chambers were filled with liquid, while ensuring the coating was in full contact with liquids on both sides.

pH measurements were done through one of the holes in the Receiver chamber using a Pt1000 probe with a $913 \mathrm{pH}$ meter from Methrohm. The measurement intervals were based on the observed diffusion rate of acid through the individual coatings. Before conducting a $\mathrm{pH}$ measurement, the liquid level in the Receiver chamber was noted. If the level had dropped, due to diffusion or evaporation, it was refilled with distilled water, ensuring a consistent volume. The $\mathrm{pH}$ probe was left in the Receiver chamber until the reading stabilized, typically after 30 seconds, and temperature readings were performed simultaneously. The $\mathrm{pH}$ probe was calibrated each week using buffered standards at $\mathrm{pH} 7.0$ and 4.0. An experiment was terminated when the concentration curve reached a steady state, typically achieved between $\mathrm{pH} 1.0$ and 2.0. 


\section{Coatings investigated}

A coating for experimentation needs to be defect-free, have a homogeneous thickness, and should preferably be as thin as possible to reduce experimental time; however, not too thin, it might produce erroneous results. Air-less spraying on a silicone slip surface was used for free-film sample production. This method resembles the application technique used in industry, however, coating thickness was influenced by this method, as a certain thickness was required to form plain, defect-free, coatings. Post-curing was performed at $60{ }^{\circ} \mathrm{C}$ for 48 hours in a heated oven. After curing, samples were cut in circular pieces to fit the cell.

Table 3 provides data on the coating formulations used for experimentation. The VE, NE1, NE2 and PU were also used for experimentation in a recent investigation on polishing rates in a pilot-scale agitated leaching reactor [3]. Due to the ease of producing a free film which was both thin and defect-free, the NE3 coating was chosen for the preliminary diffusion cell experiments. Coating $\mathrm{T}_{\mathrm{g}}$ was determined using differential scanning calorimetry, with a heating rate of 10 ${ }^{\circ} \mathrm{C} / \mathrm{min}$ from -90 to $250{ }^{\circ} \mathrm{C}$. 
Table 3: Main components of the coatings used. $R=\mathrm{Mw}_{\mathrm{Eq}}$, Curing agent $/ \mathrm{Mw}_{\mathrm{Eq}}$, Resin is the ratio of curing agent to binder equivalents, defining the relative mixture stoichiometry of functional groups. Amine types A and B contain cycloaliphatic amines, while amine $\mathrm{C}$ is predominantly aliphatic.

\begin{tabular}{|c|c|c|c|c|}
\hline Coating (code) & Resin & Curing agent & $\mathrm{R}$ & Fillers/pigments \\
\hline Vinyl ester (VE) & Vinyl ester & $\begin{array}{l}\text { Styrene (Peroxide } \\
\text { initiator) }\end{array}$ & NA & $\begin{array}{l}\text { Glass-flake and titanium di- } \\
\text { oxide }\end{array}$ \\
\hline $\begin{array}{l}\text { Novolac epoxy, } 100 \% \text { solids } \\
\text { (NE1) }\end{array}$ & Bisphenol F epoxy A & Amine $\mathrm{A}$ & 0.9 & $\begin{array}{l}\text { Quartz, baryte and titanium } \\
\text { dioxide }\end{array}$ \\
\hline Novolac epoxy (NE2) & Bisphenol F epoxy A & Amine B & 1.0 & $\begin{array}{l}\text { Talc, feldspar and titanium } \\
\text { dioxide }\end{array}$ \\
\hline $\begin{array}{l}\text { Novolac epoxy, solvent } \\
\text { based (NE3) }\end{array}$ & Bisphenol $\mathrm{F}$ epoxy B & Amine $\mathrm{C}$ & 0.3 & $\begin{array}{l}\text { Baryte, mica and titanium } \\
\text { dioxide }\end{array}$ \\
\hline $\begin{array}{l}\text { Polyurethane, } \\
\text { based (PU) }\end{array}$ & Styrene acrylate & Isocyanate & 1.1 & $\begin{array}{l}\text { Baryte, calcium carbonate } \\
\text { and titanium dioxide }\end{array}$ \\
\hline
\end{tabular}

\section{Mathematical modeling}

A model capable of simulating the transient $\mathrm{H}^{+}\left(\mathrm{H}_{3} \mathrm{O}^{+}\right)$concentration change in the Receiver cell is now described. The underlying model assumptions are given below.

- The Donor chamber has a constant $\mathrm{H}^{+}$concentration

- Chamber liquid volumes remain constant

- Liquid temperatures are constant

- The only $\mathrm{H}^{+}$ion transport resistance is in the coating (i.e. the Receiver and Donor chambers are well mixed)

- $\mathrm{No}^{+}$ions are consumed or produced in the coating film 
- No reaction is occurring in the coating film (this is a poor assumption for some coating types, as covered in the Discussion section)

- The coating has a constant thickness, equal to the dry film thickness

- The $\mathrm{H}^{+}$diffusion coefficient can vary in the coating with $\mathrm{H}^{+}$concentration

- The diffusion area remains constant

- The coating is non-porous

- The initial $\mathrm{H}^{+}$concentration in the film corresponds to a $\mathrm{pH}$ of 7

- The $\mathrm{H}^{+}$diffusion rate is not affected by liquid absorption in the coating

- $\mathrm{H}_{2} \mathrm{SO}_{4}$ is fully dissociated to $\mathrm{HSO}_{4}{ }^{-}$and $\mathrm{H}^{+}$

- $\mathrm{HSO}_{4}{ }^{-}$dissociation to $\mathrm{SO}_{4}{ }^{2-}$ and $\mathrm{H}^{+}$is considered negligible

- The diffusion coefficients of $\mathrm{HSO}_{4}{ }^{-}$and $\mathrm{H}^{+}$are assumed equal, whereby the charge balance is fulfilled throughout the coating

- The liquid solutions are considered ideal, i.e. activity coefficients of unity

The validity of these assumptions is addressed in a later section.

\section{Mass balance}

The ionic transport over the coating film is described by a mass balance for $\mathrm{H}^{+}$ions.

$$
\frac{\partial C}{\partial t}=\frac{\partial}{\partial l}\left(D_{H^{+}}(C) \frac{\partial C}{\partial l}\right)
$$


with initial and boundary conditions:

$$
\begin{aligned}
& C(l, t=0)=C_{i} \\
& C(l=0, t)=C_{D}
\end{aligned}
$$

where $C$ is the $\mathrm{H}^{+}$concentration in the coating. The transient mass balance for $\mathrm{H}^{+}$in the Receiver chamber is given by

$$
\left.\frac{d C_{R}}{d t}\right|_{l_{0}}=\frac{A}{V_{R}} \cdot F_{R}
$$

with

$$
C\left(l=l_{0}, t=0\right)=C_{R 0}
$$

where $F_{R}$ is the flux into the Receiver chamber at $l=l_{0}$ given by

$$
F_{R}=-D_{H^{+}}(C) \frac{\partial C}{\partial l} \mid l_{0}
$$

The diffusion coefficient is taken to be an exponential function of penetrant concentration [13]

$$
D_{H^{+}}(C)=D_{0} \exp (\alpha C)
$$

where $D_{0}$ and $\alpha$ are the so-called zero-concentration diffusion and plasticization power respectively [15]. Later in the investigation $D_{H^{+}}$was found to vary also with time. This timedependency was simplified by assuming a three-step time variation of $D_{0}$ : one value before acid breakthrough, one value during a transient phase, and one for the final steady state phase 
(discussed in detail later).

The model was discretized using methods detailed in [16], and numerically solved using MATLAB.

\section{Estimation of model parameters}

Table 4 provides an overview of the model input and adjustable parameters. The $D_{0}$ and $\alpha$ fitting procedure was through trial and error; a set of parameter values were examined for their ability to fit the experimental data.

Table 4: Model input parameters. $D_{0}$ and $\alpha$ are adjustable parameters.

\begin{tabular}{ll} 
Parameter & Value \\
\hline \hline$C_{D}$ & 0.13 and $1.08[\mathrm{~mol} / \mathrm{l}]$ \\
$C_{i}$ & $10^{-7}[\mathrm{~mol} / 1]$ \\
$C_{R 0}$ & $10^{-5}$ to $10^{-7}[\mathrm{~mol} / 1]$ \\
$l_{0}$ & 114 to $788 \mu \mathrm{m}$ \\
$D_{0}$ and $\alpha$ & Best fit, see Table 5 \\
\hline
\end{tabular}

\section{Experimental results}

Two types of experiments were performed using the diffusion cells. The Preliminary experiments at ambient temperature using the NE3 coating, and the Harsh experiments at elevated temperature using the VE, PU, NE1 and NE2 coatings.

\section{Preliminary conditions}

To observe the effect of water saturation, pre-saturated coatings were evaluated against dry samples. Pre-saturation was done by immersing NE3 free films in demineralized water for seven days at $21^{\circ} \mathrm{C}$, and comparing results with dry, non-presaturated NE3 films. Complete saturation was found after two days immersion at $21^{\circ} \mathrm{C}$ (not shown), using weight change experiments on films with thickness of 98 to $127 \mu \mathrm{m}$. 
The pre-saturated NE3 films had issues with crack formations in some of the films. NE3S 1, had a crack near the O-ring, as shown in Fig. 4a. This was discovered after five days, and the crack was moved out of the O-ring area, whereafter the demineralized water in the Receiver chamber was replaced to continue the experiment. As the examples show in Fig. 4, the NE3 coating films showed a slight discoloration in the acid exposed area, and some deformation of the film occurred.

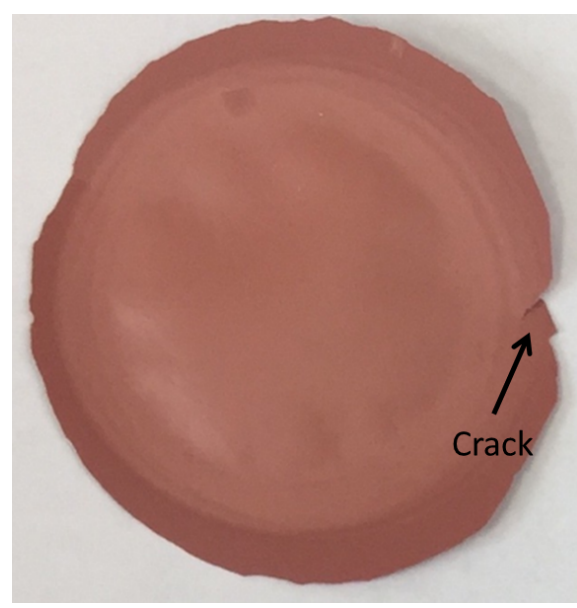

(a) Presaturated sample.

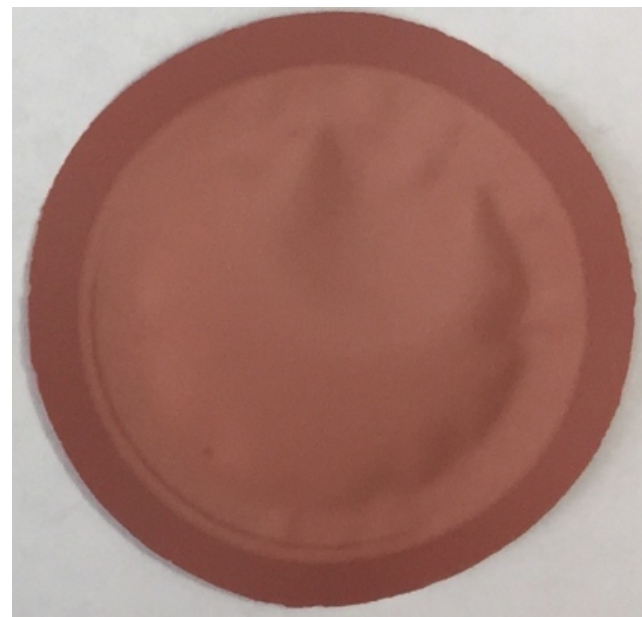

(b) Non-presaturated sample.

Figure 4: Example of NE3 coating samples after experimentation in the diffusion cell. The surface in view was the side facing the acidic Donor chamber.

The diffusion cell results are shown in Figs. 5a and 5b, which depict the measured pH values with the corresponding $\mathrm{H}^{+}$concentration for saturated and dry coatings respectively. 


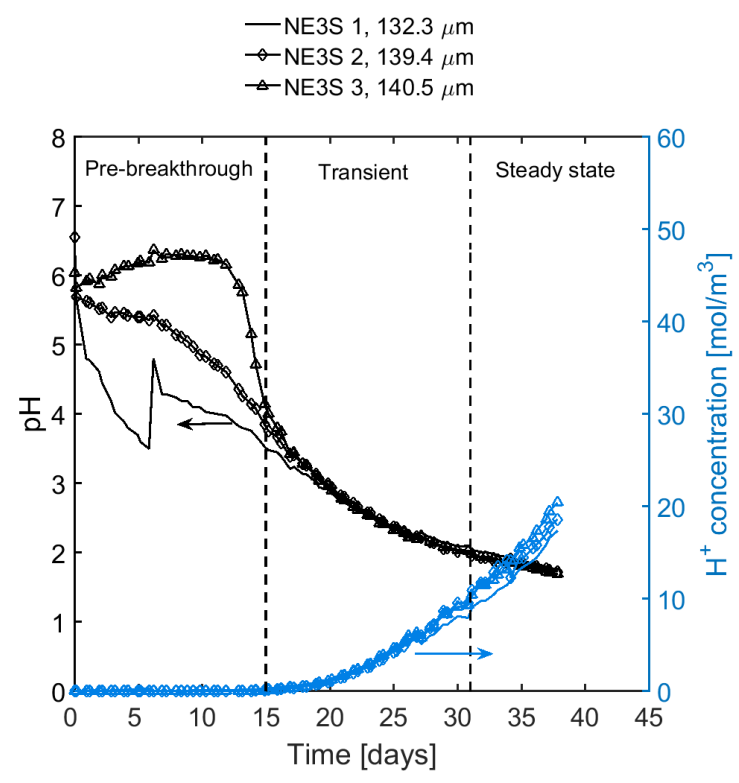

(a) Presaturated coatings.

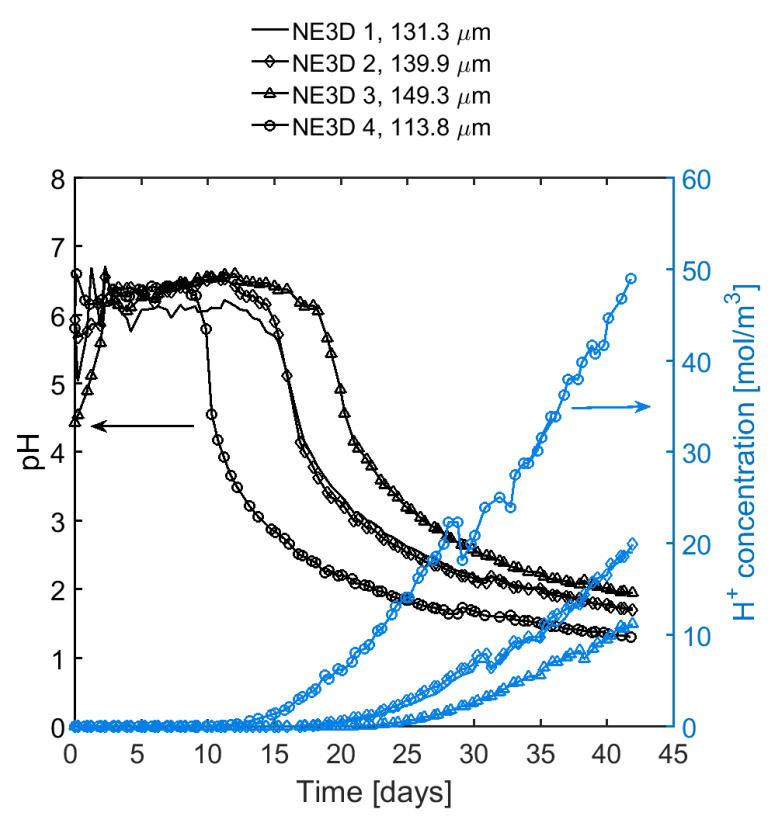

(b) Initially dry coatings.

Figure 5: Transient concentration and $\mathrm{pH}$ profiles for $\mathrm{H}^{+}$ions in the diffusion cell Receiver chamber. Diffusion was through presaturated and non-presaturated NE3 free films. Coating thickness is provided next to the sample name. Thickness measurement uncertainty was on average $5.4 \%$.

Acid breakthrough time was chosen to be the time it takes for the $\mathrm{pH}$ in the Receiver chamber to drop below 4.0. A transient state of the acid flux follows acid breakthrough, whereafter the acid flux reaches a steady state where the concentration-time curve exhibits an approximate linear slope.

The pre-saturated samples have different $\mathrm{pH}$ curves before acid breakthrough, most likely due to micro-crack formation in sample 1 and 2 as discussed earlier, but they converge in the transient and steady state period. Only NE3S 3 shows an expected trend from start to finish. The results for dry NE3 coatings are more consistent; acid breakthrough time is smaller for the thinner coatings and the $\mathrm{H}^{+}$concentration increase is transient after breakthrough, reaching a steady state after around 35 days. The small initial variation in $\mathrm{pH}$ values in the pre-breakthrough period for the dry coatings, Fig $5 \mathrm{~b}$, is caused by the lack of ions in the demineralized water 
in the Receiver chamber. A discussion on the effects of water saturation on acid diffusion is provided in a later section.

\section{Harsh conditions}

In the Harsh conditions experiments, the NE1 $\left(\mathrm{T}_{\mathrm{g}}=81{ }^{\circ} \mathrm{C}\right)$ and NE2 $\left(\mathrm{T}_{\mathrm{g}}=45^{\circ} \mathrm{C}\right)$ coatings experienced severe discoloration and blistering respectively, as shown in Fig. 6. The NE2 also developed cracks along the O-ring sealing. The PU coating discolored slightly but provided a more effective acid barrier than NE1 and NE2, even though it was operated above its dry $\mathrm{T}_{\mathrm{g}}$ of $25{ }^{\circ} \mathrm{C}$. The VE $\left(\mathrm{T}_{\mathrm{g}}=145^{\circ} \mathrm{C}\right)$ coating film did not bend like NE1, NE2 and PU throughout the diffusion experiment, but the glass flake fillers became exposed on the surface facing the Donor chamber, and detached when touched.

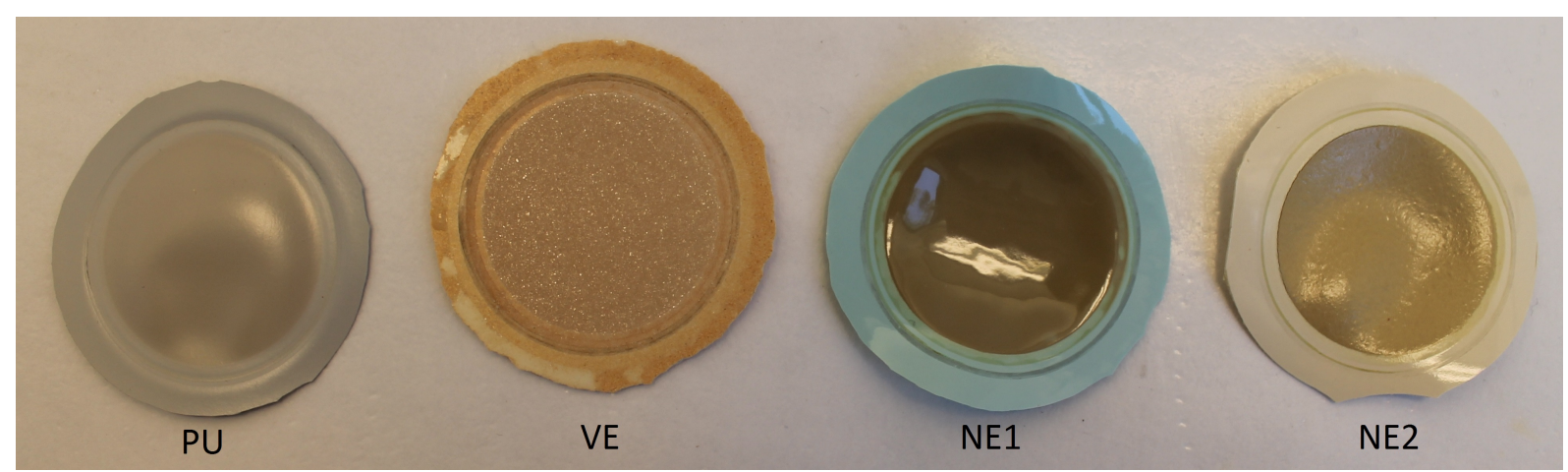

Figure 6: PU, VE, NE1 and NE2 free films after use in a diffusion cell under Harsh conditions. The surface in view was the side facing the acidic Donor chamber.

Diffusion cell results from the Harsh condition experiments are shown in Fig. 7 Note the difference in time scale on the $\mathrm{x}$-axis, as the coating performance was very widespread. Note also that the initial $\mathrm{pH}$ value in the diffusion cells varied between 4.5 and 7 . This is likely caused by the coating leaching slightly acidic (unknown) residual compounds, when contacted with the demineralized water.

The NE1 and NE2 reached a steady state $\mathrm{H}^{+}$flux rapidly after acid breakthrough, almost 
skipping the transient state that was seen for NE3 in Fig. 5. The PU showed all the expected trends of a functional barrier coating, with a transient period separating the $\mathrm{H}^{+}$flux rate between breakthrough time and steady state. The VE coating thickness was noticeably larger than the other coatings, due to application difficulties, and it showed no sign of acid breakthrough during the 118 day long experiment.

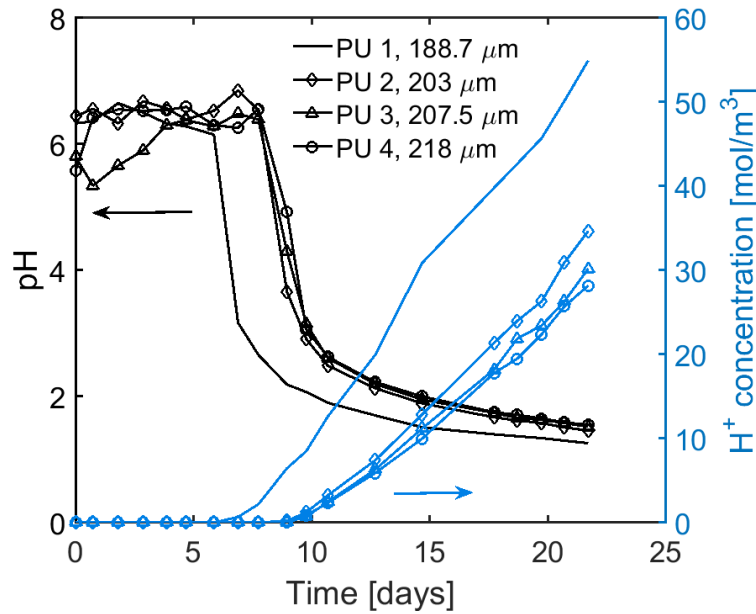

(a) PU.

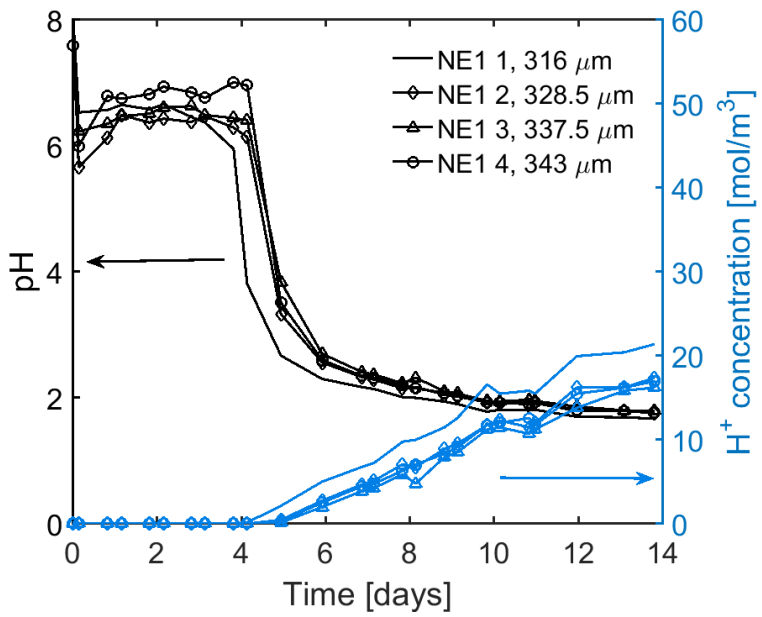

(c) NE1.

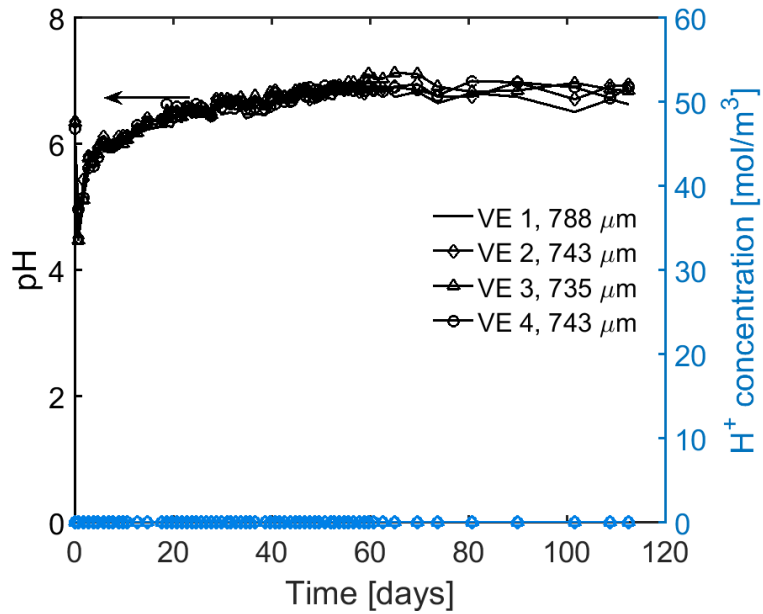

(b) VE.

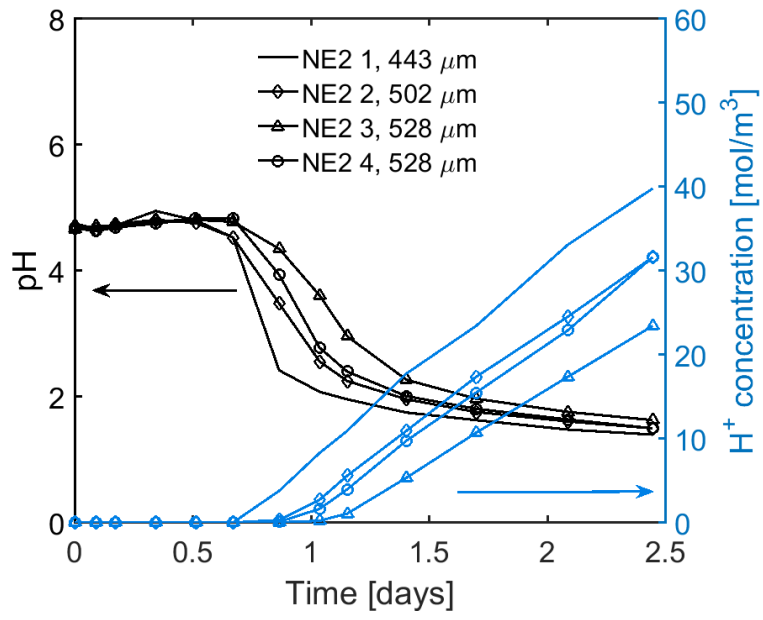

(d) NE2.

Figure 7: Transient concentration and $\mathrm{pH}$ profiles for $\mathrm{H}^{+}$ions in the diffusion cell Receiver chamber for Harsh conditions. The samples for the individual coatings varied slightly in thickness. Note the time scale differences in the figures. 


\section{Mathematical modeling of diffusion data}

To validate the mathematical model, the experimental data were simulated. The NE3D 3 coating was used as a case study, because it showed acid breakthrough, an intermediate transient concentration curve and finally, reached steady state flux conditions.

\section{Using constant diffusion coefficients}

As shown in Fig. 8, the experimental data could not be simulated using a constant acid diffusion coefficient. The model could either predict the acid breakthrough time, or the following steady state acid flux, but not both.

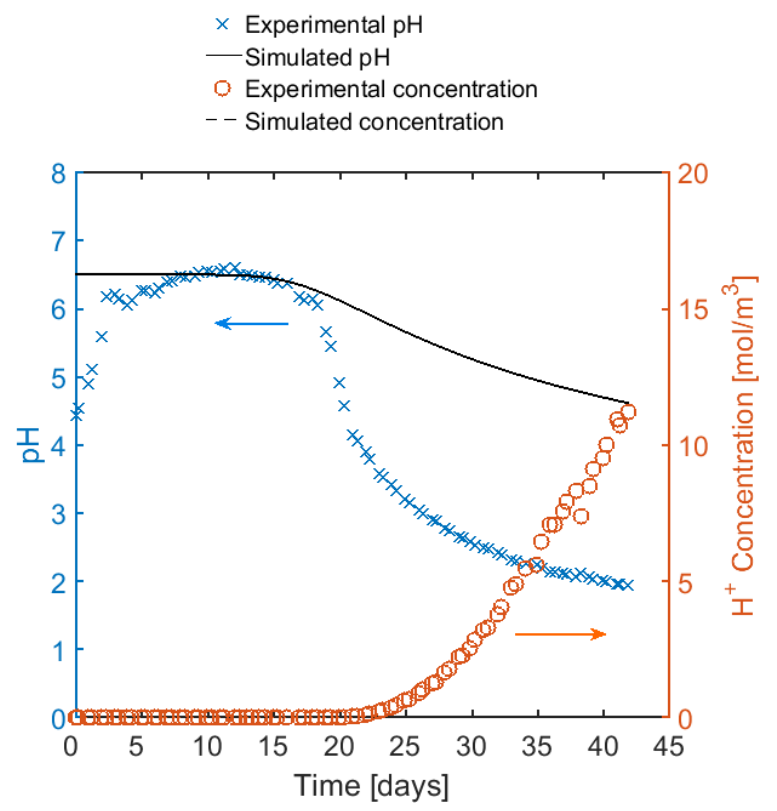

(a) $D_{H^{+}}=0.5 \cdot 10^{-15} \mathrm{~m}^{2} / \mathrm{s}$. $\times$ Experimental $\mathrm{pH}$

- Simulated $\mathrm{pH}$

- Experimental concentration

- - Simulated concentration

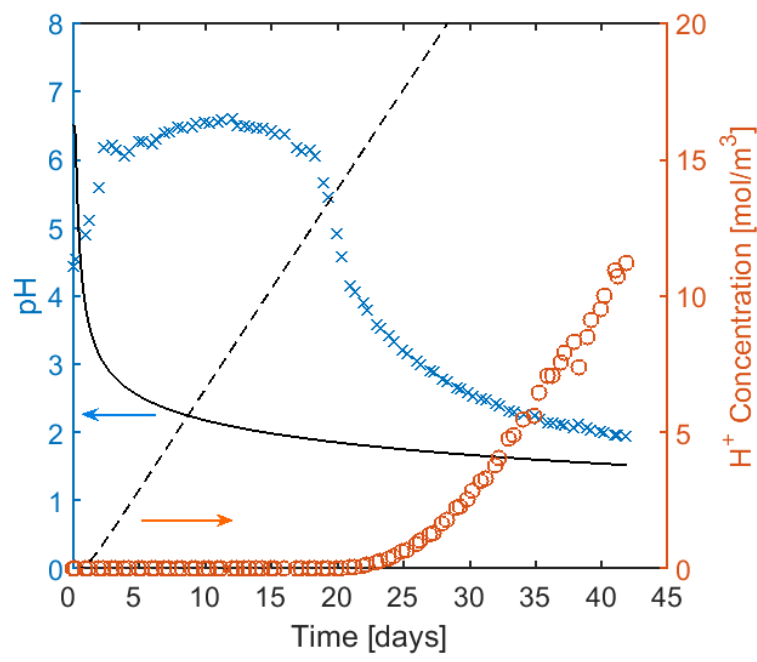

(b) $D_{H^{+}}=35.0 \cdot 10^{-15} \mathrm{~m}^{2} / \mathrm{s}$.

Figure 8: Comparison of model simulations with experimental data for NE3D 3 (constant diffusion coefficient). 


\section{Using concentration and time-dependent diffusion coefficients}

To improve model simulations, it was attempted to use a concentration-dependent diffusion coefficient. This succeeded in a better simulation of the $\mathrm{pH}$ drop after acid breakthrough. However, it still suffered from the problem discussed in the previous paragraph.

It was found that the diffusion coefficient required to simulate the acid breakthrough-time would be a factor of 18 to 190 times smaller than the value required to simulate the steady state flux. Therefore, it was assumed that the diffusion coefficient was a function of both concentration and time:

$$
D_{H^{+}}=f(C, t)
$$

The time-dependency was simplified by assuming that the pre-exponential factor, $D_{0}$, changed at the time of acid breakthrough, $t_{B}$, and after reaching the steady state flux, $t_{S S}$. A threestep time-dependency was implemented by applying one value of $D_{0}$ before acid breakthrough (denoted with the subscript $B$ ), another value during the transient phase (subscript $T$ ) and a final value for the steady state flux (subscript $S S$ ). The plastization power, $\alpha$, was assumed constant at all times.

Fig. 9 shows an example where the three sets of $D_{0}$ values have been used in the three distinct time intervals. Note the that the $D_{0 B}$ is 32 times smaller than the $D_{0 S S}$. In Fig. 10 , the simulated $\mathrm{H}^{+}$concentration profiles inside the coating film are shown, where the acid front reaches the full thickness of the film at the point of acid breakthrough of 20.5 days.

It was observed that when using three $D_{0}$ values, the breakthrough time and the steady state curve could be simulated very well. However, for the transient period some deviation between simulations and experimental data is seen. To accurately represent this part, a continuous 
variation of the diffusion coefficient over time is required, rather than the simplified three-step simulation.

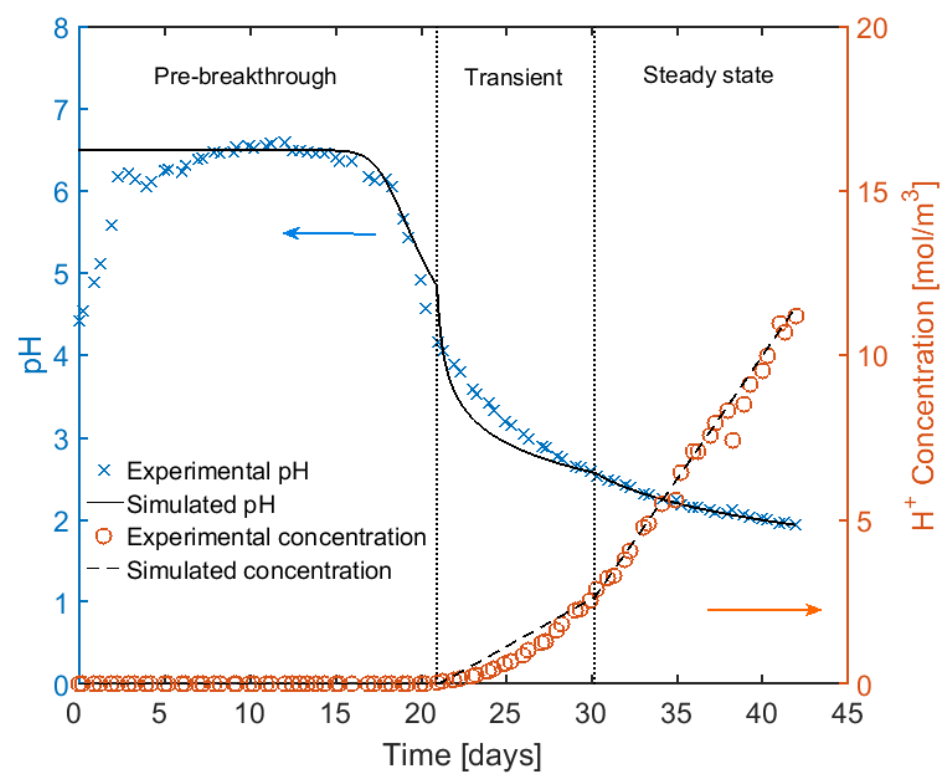

Figure 9: Comparison of experimental data and simulations of transient $\mathrm{pH}$ and concentration profiles for NE3D 3. The simulation used a diffusion coefficient which is concentration dependent, and has a three-step time variation. $D_{0 B}=0.096 \cdot 10^{-15}$ $\mathrm{m}^{2} / \mathrm{s}$ for the pre-breakthrough time, $D_{0 T}=1.1 \cdot 10^{-15} \mathrm{~m}^{2} / \mathrm{s}$ in the transient state, and $D_{0 S S}=2.8 \cdot 10^{-15} \mathrm{~m}^{2} / \mathrm{s}$ in the steady state. $\alpha=0.005$ for all values of time.

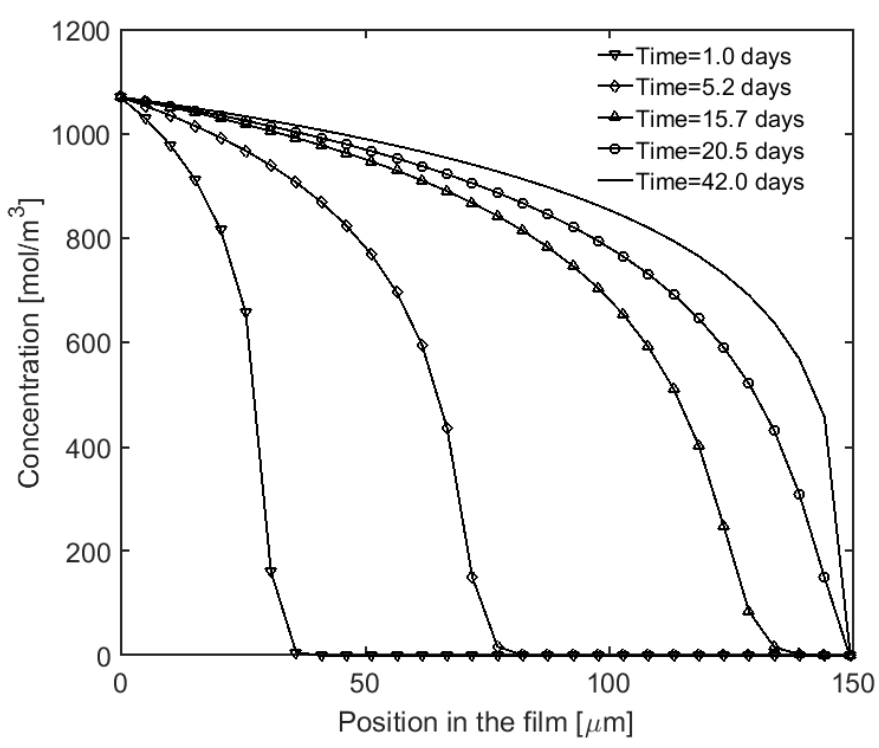

Figure 10: Simulated $\mathrm{H}^{+}$concentration profiles inside the coating film. 


\section{Discussion}

The experimental and modeling results enable an investigation into the diffusion phenomena occurring in the coating films in the diffusion cells, as well as a comparison of barrier properties and estimations of coating lifetimes. Diffusion mechanisms and the resultant diffusion coefficients are presented and discussed in this section.

\section{Coating barrier properties}

Table 5 provides an overview of the pre acid-breakthrough $D_{0 B}$, the transient state $D_{0 T}$, and the post breakthrough constants $D_{0 S S}$, as well as the $\alpha$ values, derived using the concentration and three-step time-dependent diffusion coefficient model. No acid permeated the VE samples, and diffusion coefficients could not be accurately determined for this coating type. In the literature, no studies on diffusion coefficients for VE type coatings in warm sulfuric acid have been provided. 
Table 5: Diffusion coefficients overview for all experiments conducted using diffusion cells. The coefficients shown are derived using the concentration and time-dependent model.

\begin{tabular}{|c|c|c|c|c|c|c|c|}
\hline Conditions & $\begin{array}{l}\text { Coating } \\
\text { code }\end{array}$ & $\begin{array}{l}\text { Sample } \\
\text { nr. }\end{array}$ & $\begin{array}{l}\text { Coating } \\
\text { thickness } \\
{[\mu \mathrm{m}]}\end{array}$ & $\alpha[1 / \mathrm{mol}]$ & $\begin{array}{l}D_{0 B} \cdot 10^{-15} \\
{\left[\mathrm{~m}^{2} / \mathrm{s}\right]}\end{array}$ & $\begin{array}{l}D_{0 T} \cdot 10^{-15} \\
{\left[\mathrm{~m}^{2} / \mathrm{s}\right]}\end{array}$ & $\begin{array}{l}D_{0 S S} \cdot 10^{-15} \\
{\left[\mathrm{~m}^{2} / \mathrm{s}\right]}\end{array}$ \\
\hline Preliminary & NE3D & 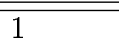 & 131 & 0.005 & 0.091 & 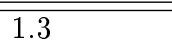 & 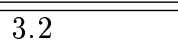 \\
\hline Dry & & 2 & 140 & 0.005 & 0.105 & 1.4 & 3.4 \\
\hline \multirow{2}{*}{$\left(21 \pm 1{ }^{\circ} \mathrm{C}\right)$} & & 3 & 149 & 0.005 & 0.096 & 1.1 & 2.8 \\
\hline & & 4 & 114 & 0.005 & 0.105 & 1.6 & 3.9 \\
\hline \multirow{3}{*}{$\begin{array}{l}\text { Saturated } \\
\left(21 \pm 1^{\circ} \mathrm{C}\right)\end{array}$} & NE3S & 1 & 132 & 0.005 & 0.16 & 1.3 & 3.0 \\
\hline & & 2 & 139 & 0.005 & 0.17 & 1.2 & 3.5 \\
\hline & & 3 & 141 & 0.005 & 0.12 & 1.4 & 3.7 \\
\hline Harsh & $\overline{\mathrm{PU}}$ & 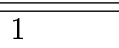 & 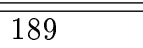 & 0.03 & 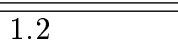 & 210 & 230 \\
\hline \multirow{15}{*}{$\left(68.5 \pm 2.5^{\circ} \mathrm{C}\right)$} & & 2 & 203 & 0.03 & 1.1 & 170 & 180 \\
\hline & & 3 & 208 & 0.03 & 1.1 & 140 & 170 \\
\hline & & 4 & 218 & 0.03 & 1.1 & 140 & 170 \\
\hline & $\mathrm{VE}$ & 1 & 788 & $0.03^{a}$ & $1.0^{a}$ & NA & NA \\
\hline & & 2 & 743 & $0.03^{a}$ & $0.9^{a}$ & NA & NA \\
\hline & & 3 & 735 & $0.03^{a}$ & $0.9^{a}$ & $\mathrm{NA}$ & $\mathrm{NA}$ \\
\hline & & 4 & 743 & $0.03^{a}$ & $0.9^{a}$ & NA & NA \\
\hline & NE1 & 1 & 316 & 0.03 & 6.0 & 290 & 290 \\
\hline & & 2 & 329 & 0.03 & 5.5 & 260 & 260 \\
\hline & & 3 & 338 & 0.03 & 5.5 & 250 & 250 \\
\hline & & 4 & 343 & 0.03 & 5.5 & 250 & 250 \\
\hline & NE2 & 1 & 443 & 0.03 & 80 & 3500 & 3500 \\
\hline & & 2 & 502 & 0.03 & 110 & 3500 & 3500 \\
\hline & & 3 & 528 & 0.03 & 100 & 1500 & 3300 \\
\hline & & 4 & 528 & 0.03 & 100 & 1500 & 3800 \\
\hline
\end{tabular}

${ }^{a}$ These are the largest possible values assuming acid penetration occurred right at the termination of the experiment. No acid breakthrough was observed and the actual $D_{0 B}$ is expected to be much lower.

\section{Coating performance and lifetime estimation}

To put the results into perspective, a $1000 \mu \mathrm{m}$ coating film is considered. The coating lifetime is defined to end when the simulated $\mathrm{pH}$ in the Receiver chamber drops from an initial value of 7 to 4 . Using the average $D_{0 B}$ and $\alpha$ values shown in Table 5 , this yields the lifetimes shown in Table 6 . 
Table 6: Coating properties and estimated lifetimes based on a $1000 \mu \mathrm{m}$ film, using average $D_{0 B}$ and $\alpha$ values from Table 5 .

\begin{tabular}{lllllll} 
Condition & Coating code & XLD $[\mathrm{mEq} /]^{a}$ & Density $\left[\mathrm{kg} / \mathrm{m}^{3}\right]$ & $\mathrm{T}_{\mathrm{g}}\left[{ }^{\circ} \mathrm{C}\right]$ & PVC [wt. \%] & Lifetime [days] \\
\hline \hline Preliminary & NE3 (Dry) & 4.49 & 1.30 & $80 \pm 2$ & 37.0 & $914 \pm 65$ \\
$\left(21 \pm 1{ }^{\circ} \mathrm{C}\right)$ & NE3 (Saturated) & 4.49 & 1.30 & $80 \pm 2$ & 37.0 & $619 \pm 120$ \\
\hline Harsh & PU & 2.13 & 1.76 & $25 \pm 2$ & 26.4 & $278 \pm 13$ \\
$\left(68.5 \pm 2.5^{\circ} \mathrm{C}\right)$ & VE & NA & 1.25 & $145 \pm 2$ & 13.1 & $>337 \pm 18^{b}$ \\
& NE1 & 7.79 & 1.39 & $81 \pm 2$ & 15.7 & $56 \pm 3$ \\
& NE2 & 6.38 & 1.29 & $45 \pm 2$ & 16.1 & $3.2 \pm 0.5$ \\
\hline
\end{tabular}

${ }^{a}$ Milimol crosslinks per liter dry coating. Theoretical value, assuming full conversion of limiting reactant.

${ }^{b}$ Very conservative estimate, assuming acid breakthrough at the termination of the experiment. The lifetime could be much longer.

The large difference in expected lifetime of NE3 coatings, compared to the rest, is likely due to the distinctive temperatures used during experimentation. Elevated temperatures will increase the diffusion coefficient according to an Arrhenius relationship [17].

As seen in Table 6, no correlation was found between expected lifetime and cross-link density (XLD), density, pigment volume concentration (PVC) or dry $\mathrm{T}_{\mathrm{g}}$ of the coating samples.

In descending order of performance, the coating barrier properties were as follows: VE $>>$ PU $>$ NE1 $>>$ NE2.

\section{Coating degradation and diffusion mechanisms}

The difference between the breakthrough and the steady state diffusion coefficient values indicates that a change is happening inside the coatings, causing a faster acid diffusion once the acid has permeated the film. It is likely that the presence of acid induces changes in the coating film, causing a reduction in the coating barrier properties behind the acid front. Hojo et al. [18] described a degradation mechanism where an ionic diffusion, followed by reactions with the resin, 
created a corroded layer, which could reduce the coating barrier properties. In a recent review [1, the amine linkage found in all NE coatings, the ester bonds in VE, and urethane linkages found in PU, were all reported as vulnerable to acid-induced hydrolysis. However, if these bonds were hydrolyzed in the present work, the coating barrier properties would also diminish after acid permeation had occurred, and a steady state flux should never be reached. Furthermore, FTIR scans of the present work (not shown) performed on the surface of the coatings before and after acid exposure, provided no evidence of hydrolysis reactions. Only dissolution of limestone filler in the PU coating was observed by the disappearance of the $\mathrm{CaCO}_{3}$ absorption peak.

For PU, the dissolution of limestone filler (initially $9.3 \mathrm{wt} . \%$ ) could provide an accessible pathway for acid diffusion. For the NE coatings, the resin-filler or resin-pigment interfaces could provide transport paths for the diffusing acid, enabling a faster diffusion rate.

Stress-cracking inside the coating film could also account for the increased diffusion coefficient. This phenomenon was observed using scanning electron microscopy inside the NE2 coating in an earlier work [3]; it was most likely caused by rapid acid permeation yielding high coating weight increase $(\approx 13 \%)$ under Harsh acidic conditions.

If the barrier properties were reduced through acid-filler interactions or stress-cracking, then once the acid permeated the entire film, a degraded coating would remain. The movement of the acid front before breakthrough, corresponding to the $D_{0 B}$ values in Table 5 , can be expressed by a virgin diffusion coefficient, $D_{\text {virgin }}$. After acid breakthrough, corresponding to the $D_{0 T}$ and $D_{0 S S}$ values, the acid flux would be a result of the degraded diffusion coefficient, $D_{\text {degraded }}$, which was found to be around one to two orders of magnitude larger than the virgin coefficient. Fig. 11 provides a depiction of the expected mechanisms. 

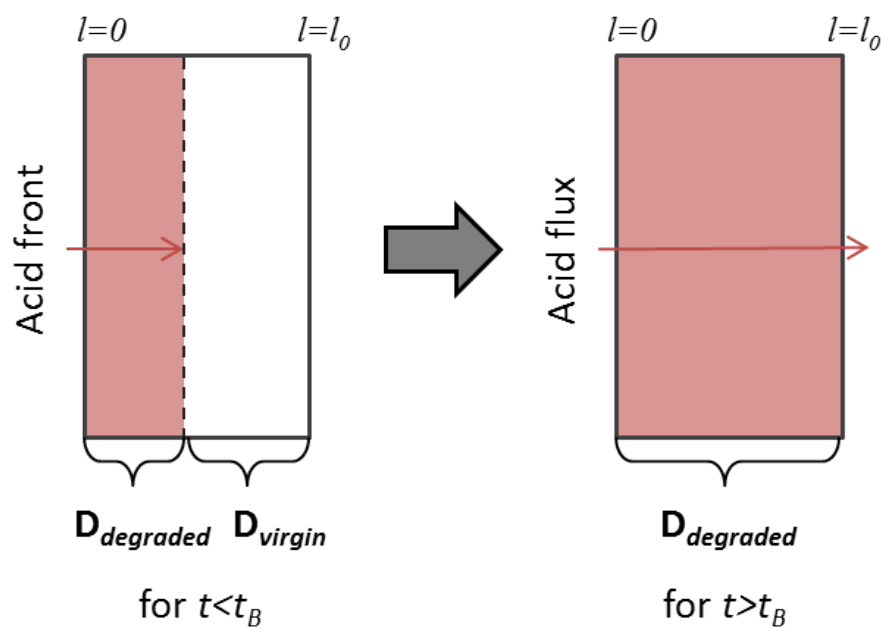

Figure 11: Time-dependent diffusion phenomena of coating films in the diffusion cell. The $D_{\text {virgin }}$ diffusion coefficient value is related to the movement of the acid front only. The $D_{\text {degraded }}$ diffusion coefficient value represents acid diffusion through the degraded coating, behind the acid front. The $D_{\text {degraded }}$ determines the steady state diffusion once the acid breakthrough time, $t_{B}$, has been reached.

\section{Water saturation effects}

Diffusion cell experiments differ from industrial applications due to the lack of a substrate, which, in the cell, is replaced with distilled water. This causes a diffusion of water from the Receiver to the Donor chamber during experimentation. The Preliminary experiments can be used to examine the effect of water saturation.

Table 5 shows no significant difference between the $D_{0 S S}$ and $D_{0 T}$ values for the dry and saturated Preliminary experiments. However, the saturated $D_{0 B}$ values are on average $33.8 \%$ higher than the dry. This indicates that pre-saturation of coatings in water speeds up the breakthrough time, but not the steady state diffusion rate. This makes sense, given that the steady state ionic diffusion always occurs through a fully water-saturated film, no matter the coating pre-treatment. The coating pre-saturation provided time for water to penetrate and plasticize the film, lowering the $T_{g}$ [19], thereby allowing a faster acid diffusion rate and yielding a shorter breakthrough time. A similar $\mathrm{T}_{\mathrm{g}}$ reduction must therefore also occur for dry coatings, due to diffusion of 
demineralized water in the opposite direction. This ultimately causes $D_{B 0}$ values estimated using the diffusion cell, to be somewhat higher than for situations where a substrate is present.

\section{Combined diffusion cell mechanism}

Based on the degradation mechanism shown in Fig. 11, and the observations made regarding the effects of water saturation, a combined mechanism to describe the diffusion phenomena in diffusion cells, observed for reactive acidic substances, can be suggested. The mechanisms are illustrated in Fig. 12. The figure depicts the diffusion phenomena observed in the diffusion cell for pre-saturated coating films and dry films, compared with the expected diffusion mechanism for industrial situations where a coating is applied to a substrate.

For pre-saturated coatings in the diffusion cell, the acid front is continuously moving through a virgin pre-saturated film, while a flux of water is occurring in the opposite direction. When the acid front reaches the Receiver chamber, the observed concentration change is determined by the acid flux through a fully degraded coating.

For dry coatings in the diffusion cell, three diffusion fronts are initially present in the film. From the Donor to the Receiver chamber, an acid front is moving through the non-saturated coating, while a water front is moving ahead of the acid front. In the opposite direction a water front is moving, reducing the $\mathrm{T}_{\mathrm{g}}$ of the affected area. When $t=t_{f}$ the acid and water fronts meet, and the acid front rate is changed, yielding a new diffusion coefficient which is around $34 \%$ larger than the dry value. This also allows a water flux from the Receiver to the Donor chamber. Finally when $t=t_{B}$ the acid front has reached the Receiver chamber, and the acid flux is occurring through a degraded coating film.

In practice, acid and water will not diffuse as a vertical concentration front, more likely they will have a concentration gradient through the coating film. The plasticization and $\mathrm{T}_{\mathrm{g}}$ reduction 
will occur over time within the water saturated area, and coating degradation will likely develop gradually within the acid exposed area.

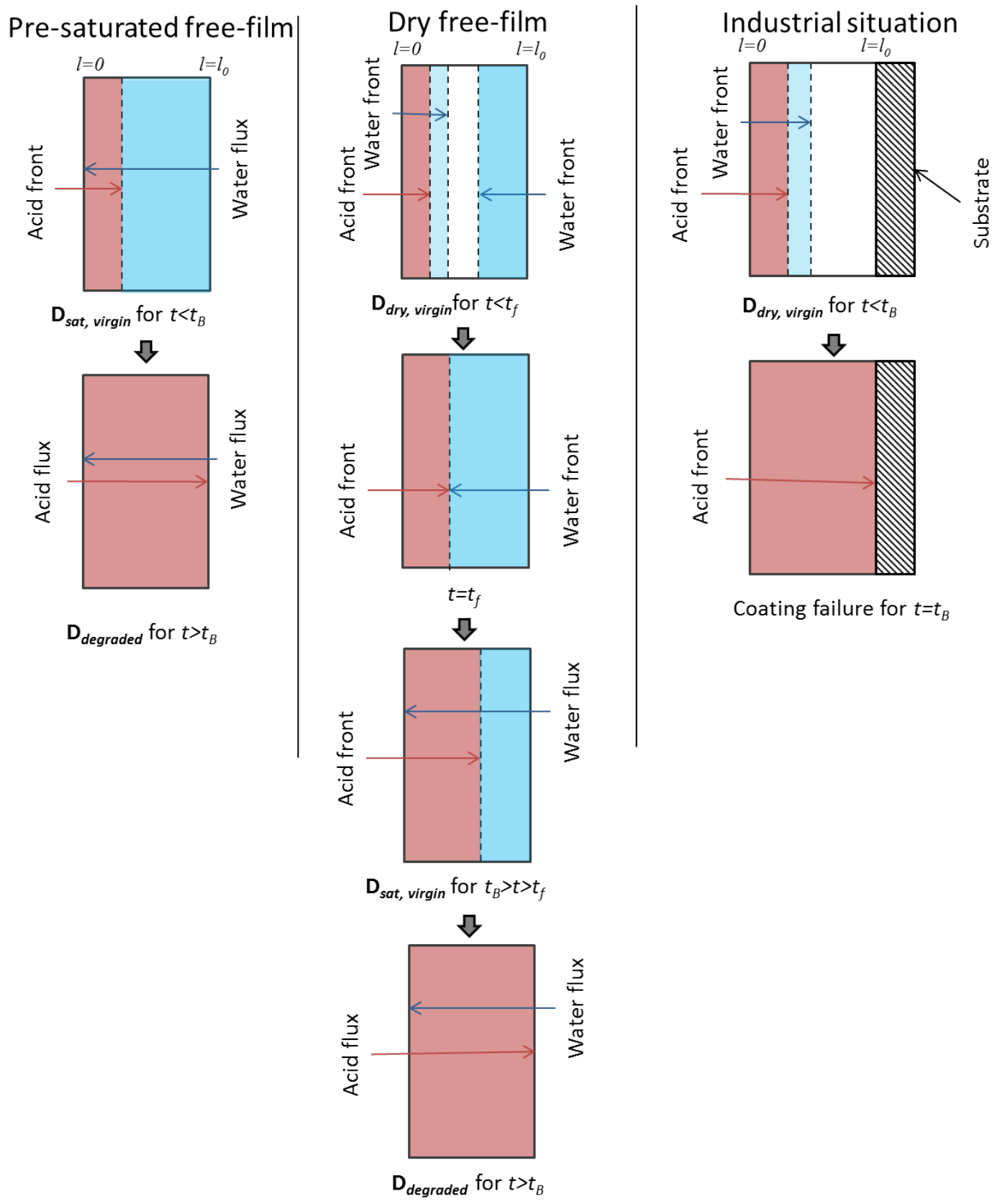

Figure 12: Diffusion phenomena of pre-saturated and dry coating films in the diffusion cell with a comparison to a real-life situation. The diffusion coefficients depicted are for acid diffusion only. $D_{s a t}$ and $D_{d r y}$ are the diffusion coefficients of acid in saturated and dry coating respectively. $t_{f}$ represents the time it takes for the water and acid diffusion fronts to meet. The $D_{\text {virgin }}$ diffusion coefficient presents the movement of the acid front before the acid breakthrough time $t_{B}$. The $D_{\text {degraded }}$ diffusion coefficient represents acid diffusion behind the acid front, and determines the acid flux through a coating after $t_{B}$. 


\section{Validation of model assumptions}

Not all the model assumptions were verified in the previous discussion, the following readdresses the most important ones.

- The $\mathrm{H}^{+}$diffusion in water was assumed to be much higher than inside the coating, allowing the boundary conditions to equate the concentrations found in the Donor and Receiver chamber. This was verified by the fact that the diffusion coefficient of $\mathrm{H}_{2} \mathrm{SO}_{4}$ in water (about $10^{-9} \mathrm{~m}^{2} / \mathrm{s}$ ) is a magnitude of five lower than the approximate one of $\mathrm{H}_{2} \mathrm{SO}_{4}$ diffusion through the coatings $\left(10^{-14} \mathrm{~m}^{2} / \mathrm{s}\right)$.

- The coating thickness was considered constant. However, the films will in practice to some extend swell or contract causing up to a $9 \%$ change in thickness [3].

- It was assumed that no $\mathrm{H}^{+}$ions are produced or consumed inside the coating due to acid-coating reaction. This assumption could not be verified.

- Electric potential gradients were neglected and the $\mathrm{H}^{+}$and $\mathrm{HSO}_{4}{ }^{-}$counter-ions were assumed to diffuse together. This is a crude assumption, especially in the pre-breakthrough period, where the ionic strength is low inside the coating film.

- It was assumed that $\mathrm{HSO}_{4}{ }^{-}$ions do not dissociate to $\mathrm{H}^{+}$and $\mathrm{SO}_{4}{ }^{2-}$. This too is a crude assumption because the pKa value of the equilibrium is approximately 2 at $25^{\circ} \mathrm{C}[20$.

In the light of the other simplifying model assumptions and the experimental uncertainty, these added complexities are not expected to improve simulations at the present stage. 


\section{Conclusions}

The new acid diffusion cell was a useful tool for analyzing coating barrier properties and estimating coating lifetime. The battery of cells used allowed a relatively fast mapping and performance comparison of a series of coating products. The cell results also provided insight into the various diffusion mechanisms.

As a barrier to sulfuric acid diffusion in conditions similar to agitated leaching conditions, the vinyl ester is the optimal candidate. Of the coatings tested, the barrier performance in descending order are: vinyl ester $>>$ polyurethane $>100 \%$ solids amine-cured novolac epoxy $>>$ aminecured novolac epoxy.

It was possible to model the diffusion behavior (breakthrough time and steady state acid flux) using a concentration and three-step time-dependent diffusion coefficient. The acid diffusion rate was greatly increased after acid breakthrough, due to a degradation of coating barrier properties, most likely caused by reactions with the diffusing acid at the resin-filler interface, or stress-cracking in the film. Water saturation of the coating film was found to decrease acid breakthrough time.

The model accuracy may be improved by including the effects of water saturation, film swelling, electric potential gradients and $\mathrm{HSO}_{4}{ }^{-}$dissociation. The nature of the acid-induced reduction of coating barrier properties, e.g. chemical reaction or cracking, needs to be better understood before it can be properly included in the model. 


\section{Acknowlegdement}

This work is part of the project 'Minerals and Cement Process Technology - MiCeTech' funded by Innovation Fund Denmark, FLSmidth A/S, Hempel A/S, the Hempel Foundation, and Technical University of Denmark (DTU).

\section{References}

[1] Møller, VB, Dam-Johansen, K, Frankær, SM, Kiil, S, "Acid resistant organic coatings for the chemical industry: a review", J. Coat. Technol. Res. 14 (2) 279-306 (2017)

[2] Duby, P, "Metallurgy", in: Kirk-Othmer Encyclopedia of Chemical Technology, vol. 16, pp. 133-164, John Wiley \& Sons (2005)

[3] Møller, VB, Dam-Johansen, K, Frankær, SM, Kiil, S, "Simultaneous acid exposure and erosive particle wear of thermoset coatings", J. Coat. Tech. Res. (2018)

[4] Hag, N, Harrison, P, "Experience with the use of Derakane vinyl ester-based GRP in flue gas desulphurization plants", Anti-Corros. Meth. Mat. 43 (2) 15-19 (1996)

[5] Häusler, E, Domagalski, P, Ottens, M, Bardow, A, "Microfluidic diffusion measurements: The optimal H-cell", Chem. Eng. Sci. 72 45-50 (2012)

[6] Yang, C, Smyrl, WH, Cussler, EL, "Flake alignment in composite coatings", J. Membrane Sci. 231 (2004) 1-12 (2004)

[7] Derocher, JP, Gettelfinger, BT, Wang, J, Nuxoll, EE, Cussler, EL, "Barrier membranes with different sizes of aligned flakes", J. Membrane Sci. 254 (1) 21-30 (2005) 
[8] Carniero, C, Oliveira, F, Nogueira, J, "Permeability of paint film towards chloride ion", J. Coat. Technol. Res. 3 (2) 2-5 (2006)

[9] Sørensen, P, Dam-Johansen, K, Weinell, C, Kiil, S, "Cathodic delamination: Quantification of ionic transport rates along coating-steel interfaces", Prog. Org. Coat. 68 (1-2) 70-78 (2010)

[10] Abastari, Sakai, T, Sembokuya, H, Kubouchi, M, Tsuda, K, "The reciprocal influence between ion transport and degradation of PA66 in acid solution", Polym. Degrad. Stab. 91 (11) 2595-2604 (2006)

[11] Pajarito, B, Kubouchi, M, "Flake-filled polymers for corrosion protection", J. Chem. Eng. Japan 46 (1) 18-26 (2013)

[12] Allen, RC, "Some corrosion mechanisms in attack of resin and resin-glass laminates", Poly. Eng. Sci. 19 (5) 329-336 (1979)

[13] Romhild, S, Bergman, G, Hedenqvist, MS, "Transport and adhesion properties of an unlined and a liquid-crystalline polymer-lined vinyl ester thermoset exposed to severe environments", J. Appl. Polym. Sci. 95 (4) 797-806 (2005)

[14] Moggridge, GD, Lape, NK, Yang, C, Cussler, EL, "Barrier films using flakes and reactive additives", Prog. Org. Coat. 46 (4) 231-240 (2003)

[15] Romhild, S, Bergman, G, Hedenqvist, MS, "Short-term and long-term performance of thermosets exposed to water at elevated temperatures", J. Appl. Polym. Sci. 116 1057-1067 (2010)

[16] Hedenqvist, MS, "Multi-layer modeling of diffusion of water in acrylamide-grafted aliphatic polyesters", Polym. Eng. Sci. 38 (8) 1313-1323 (1998) 
[17] Kiil, S, "Model-based analysis of photoinitiated coating degradation under artificial exposure conditions", J. Coat. Technol. Res. 9 (4) 375-398 (2012)

[18] Hojo, H, Tsuda, K, Kubouchi, M, Kim, DS, "Corrosion of plastics and composites in chemical environments", Met. Mater. 4 (6) 1191-1197 (1998)

[19] Croll, SG, Shi, X, Fernando, BMD, "The interplay of physical aging and degradation during weathering for two crosslinked coatings", Prog. Org. Coat. 61 136-144 (2008)

[20] Wu, YC, Feng, D, "The second dissociation constant of sulfuric acid at various temperatures by the conductometric method", J. Sol. Chem. 24 (2) 133-144 (1995) 